DOI: http://dx.doi.org/10.24093/awejtls/vol1no1.8

\title{
English and Arabic Metaphorical Conceptualization of Food: A contrastive Study
}

\author{
Hanan Zaki Alsadi \\ Language and Literature Department \\ Community college of Qatar, Doha, Qatar
}

\begin{abstract}
The purpose of this study is to compare and contrast food conceptual metaphors between English and Arabic. The researcher adopted the corpus-based approach suggested by Deignan (1995) and collected the maximum number of English and Arabic food metaphorical expressions to construct the linguistic corpus for the study. The analysis of the data was carried out for the English and Arabic languages individually following the Conceptual Metaphor Theory. The aim is to come up with a simple classification that facilitated the process of comparison between English and Arabic metaphorical expressions. The findings of the study revealed that English and Arabic share the same major food conceptualization within their scheme, namely: IDEAS ARE FOOD, TEMPERAMENT IS FOOD, GOING THROUGH AN EXPERIENCE ISTASTING IT AND GAINING MONEY UNLAWFULLY IS DEVOURING IT. Nevertheless, such conceptualizations are not equally conventionalized in the two languages due to differences between the Arabic and the western cultures.
\end{abstract}

Key words: conceptual metaphortheory, contrastive study,metaphorical mapping, source domain, target domain.

Cite as: Alsadi, H. Z. (2017). English and Arabic Metaphorical Conceptualization of Food: A contrastive Study. Arab World English Journal for Translation \& Literary Studies, 1(1).

DOI:http://dx.doi.org/10.24093/awejtls/vol1no1.8 